\title{
Developing a holistic approach to the analysis of farmer decision-making: implications for adaptation policy and practice in developing countries
}

\section{Article}

Accepted Version

Creative Commons: Attribution-Noncommercial-No Derivative Works 4.0

Singh, C., Dorward, P. and Osbahr, H. (2016) Developing a holistic approach to the analysis of farmer decision-making: implications for adaptation policy and practice in developing countries. Land Use Policy, 59. pp. 329-343. ISSN 0264-8377 doi: https://doi.org/10.1016/j.landusepol.2016.06.041 Available at https://centaur.reading.ac.uk/66969/

It is advisable to refer to the publisher's version if you intend to cite from the work. See Guidance on citing.

To link to this article DOI: http://dx.doi.org/10.1016/j.landusepol.2016.06.041

Publisher: Elsevier

All outputs in CentAUR are protected by Intellectual Property Rights law, including copyright law. Copyright and IPR is retained by the creators or other copyright holders. Terms and conditions for use of this material are defined in the End User Agreement. 


\section{CentAUR}

Central Archive at the University of Reading

Reading's research outputs online 
Developing a holistic approach to the analysis of farmer decision-making: implications for adaptation policy and practice in developing countries

\author{
Dr Chandni Singh, Dr, Peter Dorward, Dr, Henny Osbahr \\ Published in Land Use Policy, Volume 59 (2016) p329-343. \\ (http://dx.doi.org/10.1016/j.landusepol.2016.06.041)
}

\title{
Abstract
}

Smallholder farmers operate within a risky and uncertain context. In addition to climate variability and climate change, social, environmental, institutional, and market-related dynamics affect their agricultural decisions and ability to cope and adapt. In this paper, we develop and apply a set of framing questions to investigate the factors shaping farmer decision-making and how these are situated in pathways of response. Drawing on a literature review of decision-making for risk management, four questions are posed to frame enquiry: who makes livelihood decisions, why they are made, and how and when they are made. This approach conceptualises and explores household decision-making in a holistic manner, moving beyond previous studies that examine smallholder decisions through disciplinary boundaries (e.g. psychology, economics, risk management) or particular theoretical approaches (e.g. bounded rationality, theory of planned behaviour). The framing questions are used to design and interpret empirical evidence from Pratapgarh, a tribaldominated rainfed district in southeast Rajasthan, India. The findings suggest that while resource ownership and access are the main drivers of decision-making, socio-cognitive factors such as perceived adaptive capacity and perceived efficacy to carry out adaptive actions are equally important factors mediating farmer responses. We also find that the holistic approach helps explain how personal motivations and individual perceptions of adaptive capacity interact with socioeconomic, climatic, and agro-ecological dynamics at local and regional scales to mediate risk perception and inform response behaviour. Making a case for mixed methods to investigate farmer decision-making holistically, this paper provides an approach that reflects the complex and iterative nature of real farmer decision-making and can be used by researchers, policymakers, and practitioners to better understand and describe decision making and to develop informed policies and interventions.

Keywords: household decision making; socio-cognitive factors; climate variability; rainfed agriculture; adaptation 


\section{Introduction}

Agricultural decisions, especially in the rainfed context, are made in response to multi-scale and interlinked stressors on agriculture, rural livelihoods and natural resources. While there are many studies on smallholder decision-making, they have tended to be constrained by disciplinary focus, for example, within the areas of technology adoption, economics and behaviour (Ajzen et al., 2002; Marfo et al., 2008; Spielman et al., 2009). Whilst such studies have made major contributions to understanding smallholder decision-making, each disciplinary focused approach on its own is limited by not including the concepts and insights from others. More nuanced understanding of farmer decision-making is important for adaptation policy and practice in order to help identify entry points for facilitating behavioural change. There is therefore a need for examples of ways to explore decision-making that allow more holistic enquiry and understanding.

In the context of climate change adaptation (CCA), there has been relatively less emphasis on acknowledging and exploring cognitive, normative, and institutional barriers to adaptation (Grothmann and Patt, 2005; O'Brien, 2009; Frank et al., 2011; Jones and Boyd, 2011; Gifford, 2011; Grothmann et al., 2013; Shackleton et al., 2015). For example, in Western Nepal, Jones and Boyd (2011) find that social norms, which dictate livelihoods based on caste, intersect with gender, age to shape adaptation response. While in Western India, Jain et al. (2015) show risk aversion or beliefs about changes in monsoon onset to be associated with increased adaptation.

This paper has the following two main objectives: provide a way of bringing together elements of existing understanding of decision-making in a more holistic approach to better describe the range and processes of farmer responses to climatic and non-climatic risks; investigate and describe smallholder decision-making in Pratapgarh, India, a district with a predominantly tribal population dependent on rainfed agriculture. The paper reviews relevant literature before providing a set of framing questions to guide investigation of smallholder decision-making. These, together with key insights from the literature, are used to design and interpret a study (involving the use of empirical evidence from a household survey and in-depth life histories) in Pratapgarh. The paper therefore seeks to provide improved understanding of decision-making processes in Pratapgarh, new insights into decision-making and adaptation, and to contribute to ways in which decision-making can be explored in rainfed environments in developing countries. 


\section{Conceptualising household-level agricultural decision-making}

While studies have demonstrated that perceptions of exposure to climate change shape and motivate response decisions (Maddison, 2007; Slegers, 2008), the process of response decisionmaking and adaptive behaviour is still poorly understood (Gbetibouo, 2009; Williams et al., 2013). Traditional approaches to understanding farmer decision-making and behaviour have been constrained by disciplinary lenses such as economics (the 'homo economicus' (Wolf, 1990:65) was a rational, profit-maximising individual who acts to maximise utility), anthropology (agricultural choices seen as fluid and responsive to the decision-making environment) (Barlett, 1980), psychology (Armitage and Connor, 2001; Ajzen et al., 2002; Gifford, 2011), and more recently, crossdisciplinary approaches such as CCA research (Maddison, 2007; Frank et al., 2011; Williams et al., 2013; Jain et al., 2015). Farmer choices have also been explored through particular (1) theories (e.g. theory of planned behaviour, bounded rationality), (2) viewpoints such as innovation and adoption studies (Marfo et al., 2008), or (3) farming systems research (Dorward et al., 1997). Even studies on decision-making around CCA tend to focus on one or few aspects of decision-making such as temporal dimensions of risk management (Jain et al., 2015) or how social identities drive adaptation choices (Lambrou and Nelson, 2010). There is an opportunity to consider more holistic approaches to conceptualising household-level agricultural decision-making.

Inherent to the process of household-level decision-making is the understanding that farmers perceive changes in climate and non-climatic risks and then identify possible responses (Maddison, 2007). However, the relationship between perceptions and resulting behaviour is not simple, direct, or linear (Slegers, 2008). From intention to actual response, decisions are made within the context of socio-cultural norms and beliefs (Armitage and Conner, 2001; Jones and Boyd, 2011) and operate within a larger system of religious ties and common heritage. Thus, household livelihood decisions and adaptation behaviour are embedded in local and larger socio-ecological contexts.

Behavioural changes such as those involved in adaptation (and in a shorter time frame, coping), require individuals and communities to make decisions from a range of available choices. While these decisions are shaped by asset availability, time required, monetary cost (Kahan, 2008); and perceptions of risk, familiarity, and experience (Adger et al., 2009), they must also be accompanied by an intention to act (Ajzen et al., 2002). All these factors are also mediated by personal beliefs (Armitage and Connor, 2001), social identity (Frank et al., 2011), and normative beliefs held by influential people such as parents, spouse, leaders, and religious heads (Reser and Swim, 2011; Martínez-García et al., 2013). Additionally, 'perceived adaptive capacity' (Grothmann and Pratt, 
2005:202) or the decision-maker's perception about his/her 'competence' to carry out adaptive action (Kroemker and Mosler, 2002:200) shapes behaviour. Household responses to climatic and non-climatic stresses are chosen by a subjective assessment of risks and vulnerability. These responses are conceptualised as falling along a response continuum (Figure 1): from maintaining status quo (no response) to coping (short-term response, which may lead to adaptations or exacerbate vulnerability), and finally, adaptation, which implies a more permanent change with a learning component. This 'response continuum' moves beyond the simplistic dichotomy of coping and adaptive capacity similar to 'capacity to respond' (Spence et al., 2011) or 'response space' (Osbahr et al., 2011).

Figure 1 Household response strategies conceptualised along a response continuum

\begin{tabular}{|c|c|c|c|c|c|}
\hline Response & Maladaptation & Negative coping & No response & positive coping & Adaptation \\
\hline $\begin{array}{l}\text { Vulnerability } \\
\text { outcome }\end{array}$ & $\begin{array}{l}\text { Increased path } \\
\text { dependency, lock-ins, } \\
\text { higher vulnerability }\end{array}$ & $\begin{array}{l}\text { Long-term narrowing } \\
\text { of response space, } \\
\text { asset erosion }\end{array}$ & $\begin{array}{l}\text { Status quo maintained } \\
\text { but sensitive to future } \\
\text { shocks and stresses }\end{array}$ & $\begin{array}{l}\text { Slow asset accumulation, } \\
\text { leading to widening of } \\
\text { available options }\end{array}$ & $\begin{array}{l}\text { Build capacity to } \\
\text { adapt to new } \\
\text { disturbances }\end{array}$ \\
\hline Example & $\begin{array}{l}\text { Sell land, quit farming } \\
\text { to do wage labour }\end{array}$ & \multicolumn{2}{|c|}{$\begin{array}{l}\text { Pawn family assets to } \\
\text { buy poor quality seed }\end{array}$} & $\begin{array}{l}\text { Take loan and buy } \\
\text { drought-tolerant seed. } \\
\text { Store for next season }\end{array}$ & $\begin{array}{c}\text { Diversify into less } \\
\text { water requiring } \\
\text { crops }\end{array}$ \\
\hline & $\begin{array}{c}\text { Towards more } \\
\text { vulnerable system }\end{array}$ & & Response continuum & \multicolumn{2}{|c|}{ Towards sustainable } \\
\hline
\end{tabular}

Source: Singh, 2014

On the extreme left of Figure 1, households are driven by short-term gains and undertake coping strategies. Such households may either 'adapt' negatively, leading to maladaptation and erosion of system resilience (Jones et al., 2010) or manage crisis-like conditions by meeting immediate needs (Adams et al., 1998). Towards the centre, households maintain status quo by protecting their natural and social assets from severe erosion (Rademacher-schulz et al., 2014). Towards the right, households cope positively and undertake longer-term adaptive responses. Livelihood portfolios are adjusted to reduce current and potential vulnerability by taking into account trends of climatic and non-climatic stressors (Williams, 2013; Rademacher-schulz et al., 2014) as well as dynamics in the local and wider socio-ecological landscape. Such 'successful adaptors' proactively avoid high-risk challenges that result in potentially negative changes and take advantage of developing opportunities (Park et al., 2012). On the far right, the rainfed agricultural system (of which a rural household is a part) is conceptualised to undergo transformation, signifying a change in the 'state of the system' (Walker et al., 2004). 
While the response continuum concept provides a framework on which to place farmer livelihood strategies and understand decision-making, actual farmer strategies are more a basket of coping, maladaptive, and adaptive strategies rather than a binary where household members choose one strategy type. Therefore, multiple decisions may be made by different household members which interact to make households take different pathways (Figure 2): they may spiral downwards from transitory to chronic poverty, get locked into cycles of deprivation, or make incremental adaptations through successful coping.

Real-time dynamic decision-making is usually a 'plurality of sub-decisions' (Mintzberg et al., 1976:252) without any definite, linear sequence and is more closely a 'continuous flow of behaviour toward some set of goals rather than as a set of discrete episodes involving choice dilemmas' (Brehmer, 1990:26). Thus, we conceptualise decision-making as a process where although distinct phases can be delineated, they have several feedback loops and iterations of adjustment.

Figure 2 Households undertake different response pathways

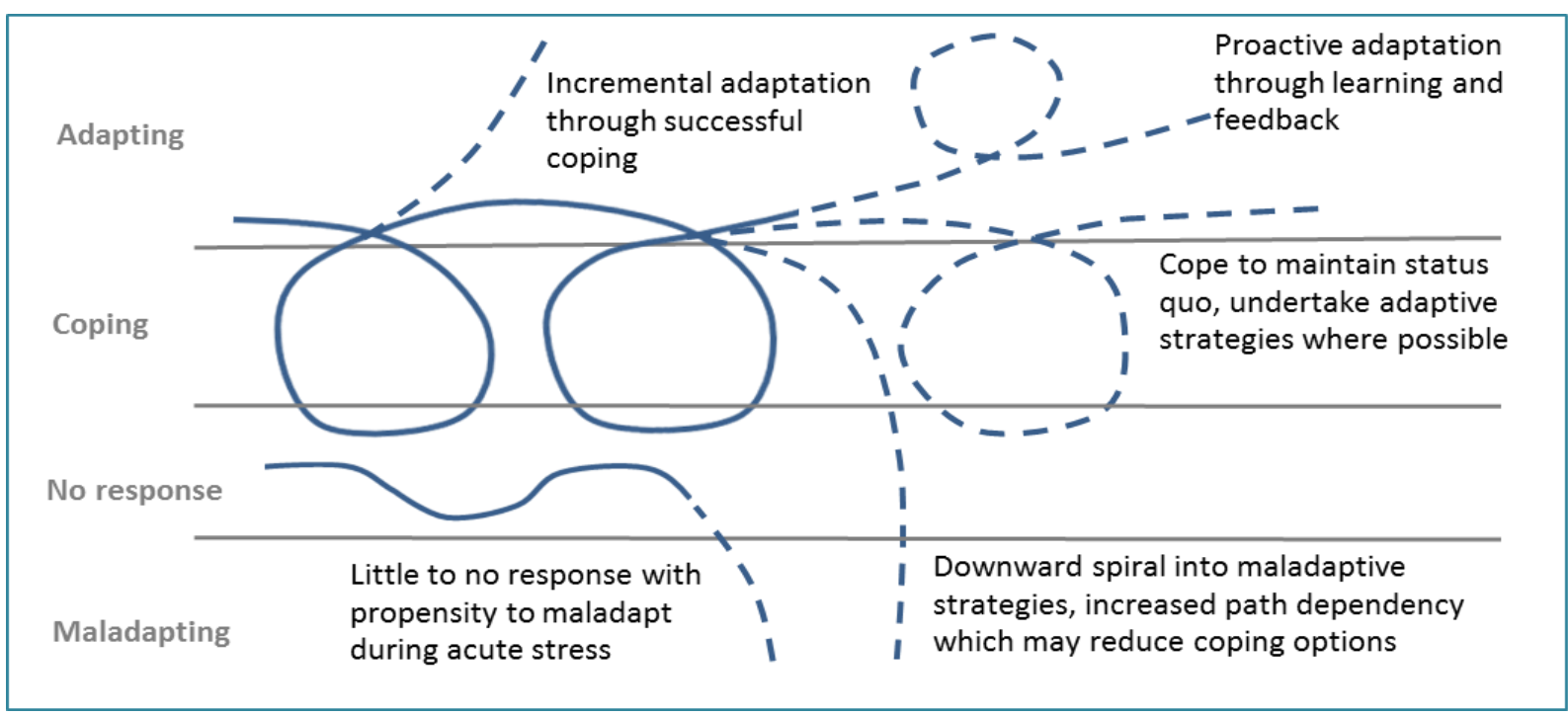

Author construct

Decisions to adapt are taken at various scales: by individuals in response to climatic events and socio-economic dynamics, by communities to reduce collective risk (Adger, 2003), and by governments on behalf of society (Adger et al., 2003). These decisions are embedded in social processes that are constantly negotiated across scales, moving from individual assets and capabilities (Bebbington, 1999), intra-household dynamics (Agarwal, 1997), and social networks (Adger, 2003) towards wider politico-legal dynamics. Decisions are also taken across temporal scales 
(e.g. farmer decisions before, in and after a cropping season) with more risk attached to immediate and personally relevant threats compared to those expected in the future. It is important to note that historical marginalisation and notions of inferiority can also lead to 'aspirations failure' (Dalton et al., 2015:165), which, in the context of poverty traps, is 'the failure to aspire to one's own potential'.

Falling between individual and group decision-making are decisions made by households. While it is often assumed that all household members are driven by similar motivations and aspirations, thus behaving as a homogenous unit, a household as a group of people must negotiate member decisions based on their role and place within the household (Agarwal, 1997). Household decisions often involve trade-offs where individual interests are sacrificed for collective benefits and long-term objectives.

Decisions in smallholder agriculture are made in response to and anticipation of climatic and nonclimatic dynamics. Using an interdisciplinary approach to understand the decision-making process, this paper seeks to build on other studies that have explored one or few aspects of decision-making. Drawing on the above understanding of decision-making, four questions are posed to frame enquiry: (1) what response strategies are undertaken by households in rainfed contexts; (2) who is making what decisions; (3) when do households make decisions and why do they make them (factors affecting decision-making); and (4) how does the decision-making process evolve.

\section{Methodology and study area}

\subsection{Smallholder farming in Pratapgarh}

To explore farmer decision-making in a rainfed context, we chose Pratapgarh, a district in Rajasthan, northwest India because it provides a useful context of the livelihood, natural resource, socioeconomic and climatic dynamics that characterise uncertainties associated with rainfed agriculture in India and the developing world. While we acknowledge that conditions vary with location and context, the Pratapgarh case study illustrates a story that is familiar across rainfed India. Although Pratapgarh receives relatively high levels of rainfall (annual average of 850-1000 mm), it also faces severe droughts (Government of Rajasthan, 2011) and high intra-season rainfall variability (Singh, 2014). Strong dependence on the southwest monsoon for rainfall makes farming sensitive to increasing climatic variability. Regional climate change is projected to exacerbate agricultural vulnerability through scantier and more erratic precipitation (Rupa Kumar et al., 2006), rising 
temperatures (Mall et al. 2006), and increasing evapotranspiration rates (Goyal, 2004). Farmers in Pratapgarh are also exposed to non-climatic dynamics such as market fluctuations and institutional changes (e.g. land tenure reforms). Additionally, tribal farmers have a history of socio-political marginalisation, allowing us to understand how such differences mediate household decisionmaking and responses.

Of the respondents ( $n=220$ ), $89 \%$ were Meena (tribal) farmers, while $11 \%$ were Rajputs (historically part of the privileged warrior caste). Average landholding size was 0.9 acres, and households typically comprised 5-7 members. Of the households interviewed, $49 \%$ fell below the poverty line and $90 \%$ were male-headed families.

Based on this study's questionnaire, households in local communities primarily depend on rainfed subsistence farming (47\%) and wage labour for income (40\%). Other sources of income (representing less than $5 \%$ each) include petty trade, family networks, state pension and tendu leaf collection. Main crops grown are soybean, maize, and cotton in the rainfed kharif season, and gram and wheat in the winter rabi season. Households also engage in several secondary livelihood activities (either singly or simultaneously), depending on season and availability. These activities include livestock rearing, unskilled wage labour, seasonal migration to neighbouring urban centres, and collection of non-timber forest products (NTFPs) ${ }^{1}$.

However, the mix and balance of livelihoods are changing. Increasing population and land fragmentation are driving cultivation of private grazing lands and decreased livestock ownership (Foundation for Ecological Security, 2009). Lack of water is causing tendu trees to dry up, affecting incomes from NTFPs. These changes are increasing reliance on agriculture. In the inadequate presence of supporting infrastructure, agricultural incomes are undermined at pre-sowing (inadequate seed availability), in-season (poor irrigation infrastructure), and post-harvest (poor market linkages) stages.

\subsection{Livelihood decisions and decision-making processes}

This paper uses data from a larger study that explored drivers of farmers' differential vulnerability to water scarcity and climate variability (Singh, 2014). The unit of analysis is the farming household

\footnotetext{
${ }^{1}$ Common NTFPs in Pratapgarh include tendu (Diospyros melanoxylon) the leaves of which are used to make unfiltered Indian cigarettes, ratanjot seeds (Jatropha curcas) for extracting oil, puvaad (Cassia tora) for cattle feed, baheda (Terminalia bellirica) and aamla (Emblica officinalis) used in Ayurvedic medicines and mahua (Madhuca longifolia) the flowers of which are used to make liquor.
} 
because in the Indian context, the entire household is closely involved in farming and other livelihood activities. Other actors (community members, local bodies, government officials, market actors, and civil society organisations) are external but interacting with households.

Within Pratapgarh district, nine villages were chosen through stratified purposive sampling to represent a range of household types (based on farm size, caste, agro-ecological conditions, and willingness to participate). The methodological approach taken was appropriate to this study because it drew on a combination of quantitative and qualitative data to enable detailed understanding of processes and to support generalizable findings. A household-level semi-structured questionnaire was used to collect quantitative and qualitative data. Questions focused on livelihood and farming strategies to understand decision-making holistically and avoid leading questions on CCA. Men and women were interviewed in same household separately to capture nuances in choices and decision-making differentiated by gender. The questionnaires were complemented by key informant interviews and focus group discussions (Table 1). A local NGO helped with introductions to local leaders and government officials, arranged translators, and access to climatic data. Ethical protocols to maintain respondent anonymity were followed and selection of research participants was informed by the lead author's immersion in the research site over 10 months which allowed familiarisation with the context and countered potential influences/biases that the NGO or elite influence could have caused. Since the data collector was female, translators were young males. This allowed access to male-dominated spaces such as the Gram Sabha (village meetings) and enabled conversations with women since young males were perceived less as threats and more as sons.

Table 1 Field methods used to collect data

\begin{tabular}{|c|c|c|}
\hline Method & Number & Activities undertaken and relevance to research \\
\hline $\begin{array}{l}\text { Household } \\
\text { survey }\end{array}$ & 220 & $\begin{array}{l}\text { Semi-structured questionnaire with closed and open-ended questions } \\
\text { on (1) exposure to climatic and non-climatic stressors, (2) household } \\
\text { vulnerability and response strategies, and (3) actors, timing and } \\
\text { motivations for livelihood decision-making. }\end{array}$ \\
\hline $\begin{array}{l}\text { In-depth life } \\
\text { histories }\end{array}$ & 14 & $\begin{array}{l}\text { Detailed interviews with as many household members as possible on } \\
\text { decision-making processes, intra-household roles and dynamics, } \\
\text { family histories and livelihood strategies. Seasonal calendars for } 2011 \\
\text { and } 2012 \text { made to contrast a good and bad year and used as } \\
\text { discussion tools to explore drivers behind decisions taken. }\end{array}$ \\
\hline $\begin{array}{l}\text { Focus group } \\
\text { discussions }\end{array}$ & $\begin{array}{l}6 \\
\text { (mixed gender } \\
\text { groups with 4-5 } \\
\text { participants/group) }\end{array}$ & $\begin{array}{l}\text { Exploratory group discussions using open-ended questions. Used } \\
\text { participatory techniques like risk ranking exercises and causal } \\
\text { diagrams (to discuss coping and adapting strategies), seasonal } \\
\text { calendars and timelines (to capture short-term and long-term village- } \\
\text { level socio-economic and climatic changes), and participatory village } \\
\text { mapping (to map resource access). }\end{array}$ \\
\hline $\begin{array}{l}\text { Key informant } \\
\text { interviews }\end{array}$ & 36 & $\begin{array}{l}\text { Semi-structured interviews with farmers, shopkeepers in } \\
\text { neighbouring towns, government officials, and NGO workers. }\end{array}$ \\
\hline
\end{tabular}


Questions tailored for each interviewee to understand beyond-village dynamics affecting rural livelihoods and triangulate findings about climatic variability, market dynamics and ongoing development projects.

In the second phase of fieldwork, 14 households were purposively chosen to capture various response strategies. Each case selected represented a household 'type' which emerged from broad trends in the household survey and captured social stratification (caste, gender of household head, position in village) and asset stratification (landholding size, economic status). Some cases were selected, despite not being representative, because they provided interesting insights into proactive decision-making and could serve as examples of successful household-led adaptation. In-depth life histories (Bagchi et al. 1998) were developed to study livelihood trajectories and processes of adaptation decision-making through open-ended conversational interviewing over 3-4 days. Men and women within the household were interviewed separately to elicit information on differing decision-making roles and care was taken to adhere to cultural norms. Data were collected during monsoon (kharif) and winter (rabi) seasons during September 2011-June 2012, and farmers were asked to recall response strategies over a ten-year period prior to fieldwork. The qualitative data were analysed using NVivo (QSR International, 2010) using an iterative process to develop codes as new themes emerged (Robson, 2002). The coded responses were then analysed along socioeconomic and demographic variables. Visual qualitative data like seasonal calendars and timelines, were visually compared (placed one below the other) to study areas of overlap and mismatch. The next section presents the results using the framing questions of what decisions are taken, by who, when, for what reasons, and how does the process evolve.

\section{Results}

\subsection{What decisions are farmers taking?}

Coping strategies revolved predominantly around ensuring food security, supplementing income, and adjusting farming practices (

Table 2). Households undertook agricultural activities with minor, season-specific changes and used social safety nets and state-funded welfare goods to maintain baseline but non-life-threatening risk.

Farmers also undertook various adaptive strategies in tandem, such as modifying agricultural practices, diversifying credit access, engaging in better water management, and diversifying income sources. The most commonly used strategies were adjustment of agricultural practices by 
diversifying crops grown (86\%) and altering sowing times (87\%). Although adaptive strategies were largely individual efforts dependent on individual resourcefulness and social capital ( $82 \%$ buy food from markets, $79 \%$ undertake daily wage labour), $20 \%$ households undertook soil and water management on their land under an ongoing NGO-led watershed management project. These decisions reflect coping and adaptation strategies from the response continuum (Figure 1).

Table 2 Household coping and adaptive strategies ${ }^{*}(n=220)$

\begin{tabular}{|c|c|c|}
\hline Coping strategies & & $\begin{array}{c}\text { \% of households using } \\
\text { strategy }\end{array}$ \\
\hline \multirow{4}{*}{ Change in agricultural practices } & Leave land fallow in one season & 72 \\
\hline & Second sowing & 32 \\
\hline & Sharecropping & 5 \\
\hline & Leave land fallow all year round & 4 \\
\hline \multirow{6}{*}{ Ensuring food security } & Buy food from market & 82 \\
\hline & Store seed from home & 37 \\
\hline & Decrease food intake & 46 \\
\hline & Store food & 27 \\
\hline & Buy food on credit & 2 \\
\hline & Source food from relatives & 2 \\
\hline \multirow{3}{*}{$\begin{array}{l}\text { Exploiting social welfare } \\
\text { programmes and safety nets }\end{array}$} & Government welfare schemes** & 34 \\
\hline & Loans from relatives & 18 \\
\hline & Distribute responsibilities among relatives & 4 \\
\hline \multirow{8}{*}{$\begin{array}{l}\text { Temporary credit access and } \\
\text { life maintaining strategies }\end{array}$} & Daily wage labour & 79 \\
\hline & Government aid*** & 41 \\
\hline & Loan from moneylender & 31 \\
\hline & Pawn jewellery & 33 \\
\hline & Sell few livestock & 25 \\
\hline & One-time seasonal migration & 21 \\
\hline & Sell all livestock & 19 \\
\hline & Mortgage/sell land & 7 \\
\hline Erosion of human capital & Stop children's education & 25 \\
\hline \multicolumn{3}{|l|}{ Long-term adaptive strategies } \\
\hline \multirow{4}{*}{ Altered agricultural practices } & Multiple cropping & 86 \\
\hline & Altering sowing time & 87 \\
\hline & Grow less water requiring crops & 39 \\
\hline & Grow more food crops & 25 \\
\hline \multirow{2}{*}{ Water management } & Soil/water management work & 20 \\
\hline & Improved irrigation methods & 3 \\
\hline Livelihood diversification & Regular seasonal migration & 40 \\
\hline Credit access & Loan from bank + crop insurance & 42 \\
\hline
\end{tabular}

* Strategies demarcated as coping or adaptive by the researcher based on whether it was a short-term adjustment or long-term change. Households perform more than one type of response strategy in a year.

** For example Food for Work Programme *** Aid in terms of money (drought relief) 


\subsection{Who is making what decisions?}

Overall, men were chief decision makers (Figure 3). Household heads made decisions, either individually or in consultation with the family. In male-headed households, men made agricultural and domestic decisions, and women were consulted. Here, consulted does not equal participation, empowerment or increased agency and male respondents used the word "biwi se poocha" which means "asked my wife". Even when the spouse was consulted (or more accurately, asked), the male household head made the final decision on agricultural matters. Box 1 examines four illustrative households to highlight how intra-household dynamics drive decision-making.

Figure 3 Decision makers (left) and decision-making processes (right) in households
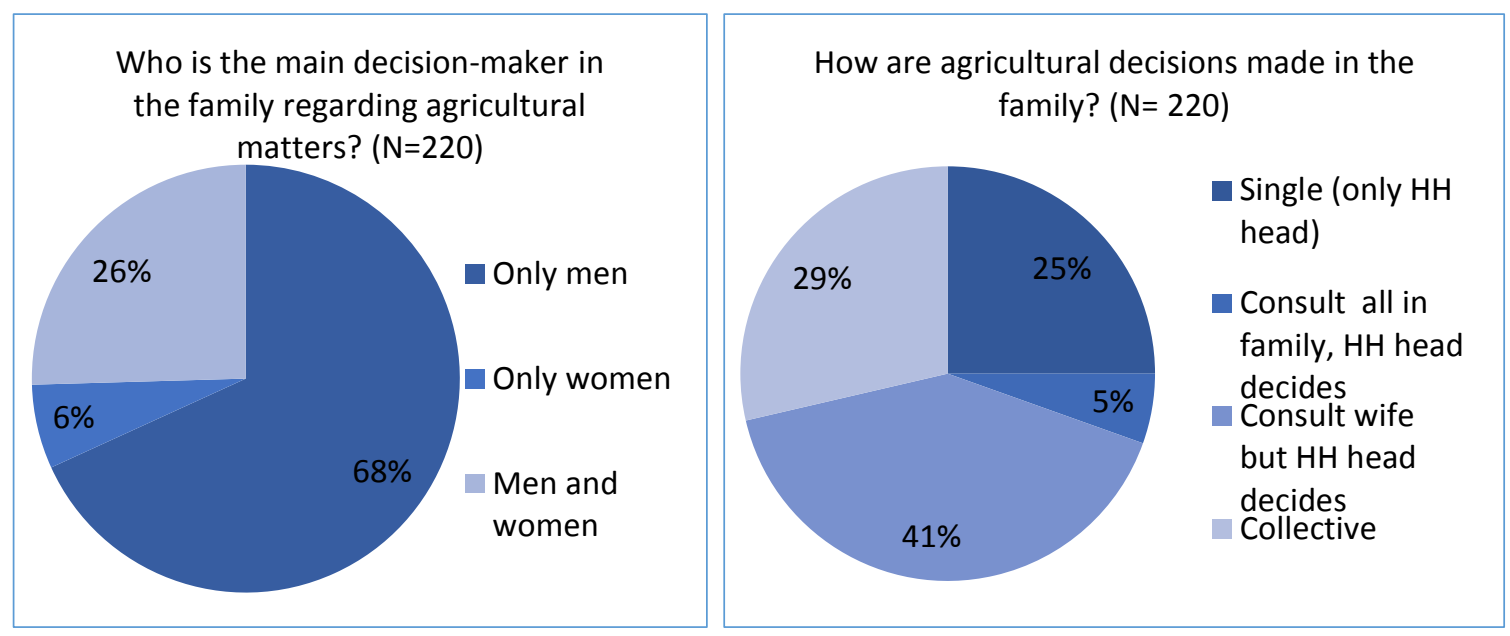

Who made decisions depended on individual characteristics of household members (gender, age, education) and intra-household dynamics shaped by normatively demarcated roles which could be along lines of gender (for example women tend to address drinking water needs, men handle irrigation) or different (women do not necessarily participate in village meetings). Within maleheaded households, if women were educated, had a strong character, and were treated as equals, their opinion was considered. For example, Sohana (CS1, Box 1), was a vocal contributor to financial decisions which are traditionally male-dominated. This was because engagement with a local NGO over seven years had taught Sohana credit management. Regular training programmes and demonstration visits had exposed her to women in strong roles. Having a supportive, ambitious husband helped her articulate and realise her own ambitions for her household. However, this was not the norm: only $29 \%$ households reported collective decision-making (male members making decisions with little or token consultation with female members). Within this, there were varying degrees of participation and acceptance of opinions. Most households (41\%) reported that though the household head consults his spouse, the final decision is taken by the head. Male-led decisionmaking (Mohan, CS4 in Box 1) was closer to the norm than Sohana's case. 
Box 1 Four cases illustrating how household assets, individual personality, and intra-household dynamics interact to affect response decisions

Agricultural decisions are made by the male household head; the wife is consulted on domestic decisions.

Mohan [CS4] is a smallholder farmer living with wife, 2 sons and 2 daughters. He co-owns 0.5 acres land and one well with his brother. Mohan and his wife are illiterate and one son attends school (the remaining three children dropped out). One son works as a labourer in Pratapgarh. Mohan has a debt of INR20000 (\$307) from local moneylenders. He makes all decisions (agricultural and domestic) and takes the opinion of his wife. The elder son is not consulted as he does not help on the land, except during harvesting. The other children are young.

'I make farm-related decisions alone - my sons are not even interested. My wife gives her opinion about how much wheat or vegetables we need. She is restricted to housework, tending to the kids, and feeding the cattle. In 2006, I took a loan to buy land with my brother and on that land we both jointly decide what to grow. My brother and I discuss agricultural matters but we seldom talk to our wives.'

Educated couples make joint decisions with equal roles for male and female members.

Khemraj [CS1] is a smallholder farmer living with wife Sohana, 2 daughters and 2 sons. He and his wife are educated until middle school and all their children are attending school. He shares three wells with three brothers and their land in his father's name. He has strong ties with local shopkeepers, NGO workers and extension officers. His wife is the treasurer of a local Self-Help Group (SHG). Agricultural decisions are discussed by all male members of the extended family. Wives are seldom consulted though sometimes their opinion is sought. At the household level, Khemraj and Sohana have an equal say in cropping and domestic decisions. Sohana also gives financial advice because of her role as treasurer in the SHG.

'For any decision regarding the land (e.g. building a well), money (taking large loans) or family (brother's marriage), my father makes the decision. The land is in his name so he signs the paperwork. He has his contacts and is respected in the village. For farm decisions on my land, I decide, and Sohan a gives her inputs. For household decisions, Sohana has the final word. She is very strict about household finances and knows how to maintain accounts.'

In Rajput households, agricultural decision-making is completely male-dominated.

Madhav Singh [CS8] is a Rajput large landholder living with wife, two sons, their wives, and five grandchildren. He has a large brick house, tractor, 3 cows and 2 wells. Decision-making is restricted to men. The wife of the male-head is consulted but younger female members (e.g. the daughters-in-law) have no say.

'I make all decisions and consult my sons about what to grow. I talk to my wife about these things sometimes but she doesn't know much'. His wife added, 'Agricultural decisions? No, no. I have not even seen my fields properly! We do not step out of the house. If we do need to go for a wedding or birth ceremony, my husband or sons accompany me. Agriculture is for men, we don't know anything about it so how can we contribute?'

In households where there is a male, elderly patriarch, decision-making is an individual process.

Baaghchi is a 72-year-old tribal farmer with two wives and two corresponding households. He divides his time between his family with the older wife and three sons, and younger wife with one son, one daughter. He is a medium landholder, has two wells, several farm implements and 12 heads of livestock. He is illiterate but is the village head and commands respect in the area. All decision-making is done by Baaghchi with negligible consultation with wives. Sons are sometimes consulted in agricultural decisions but never in financial matters. Sons' families are dependent on Baaghchi for food.

'I make all decisions since I know what is best for the family. The women are restricted to housework and looking after children and cattle. I consult my sons but they fight and I have to make sure everyone gets an equal share of grain from the land.'

Source: In-depth life histories 
There was a sharp distinction in the level of engagement of women in Rajput and tribal households (Box 1 discusses three tribal and 1 Rajput household). Rajput women were restricted to domestic duties and did not participate in agricultural decisions or activities (CS8). Decision-making in Rajput households was male-dominated because living in a joint family necessitated collective decisions sensitive to views from all (male) family members. Age played an important role in decision-making. Young children (below 15 years) were not included, while older children were consulted because they went to school and were perceived as contributors of valuable information. Very old people lived separately and did not play a role in decision-making. Where land was in the name of the family patriarch (for example CS2), the household head made agricultural decisions, with some consultation with his sons. In such houses, the wife was rarely consulted and the daughters-in-law, never. Thus, seemingly homogenous decisions may mask strong intra-household differences and explain how response strategies may be skewed to benefit some household members while constricting spaces for dissent or discussion.

These characteristics of decision-making operate during normal climatic variability. During a crisis, men were key decision makers except when they travelled (for example, prolonged migration in drought years). Then, women either implemented decisions made by their husbands or in case of longer periods of absence, made decisions themselves. However, in such cases, women expressed hesitation because they perceived themselves ill-equipped to make sound choices because men were considered more 'suitable' to make farm-related decisions.

\subsection{Why and when do farmers make the decisions they do?}

Farmers in Pratapgarh chose response strategies based on stressor severity, risk perception, available resources, perceived ability to respond, and external support. The results reflect the pathways diagram (Figure 2) and illustrate how climate factors are interlinked with broader agricultural issues.

\subsubsection{Operating in uncertainty: experienced stressors and expected risk}

Within an agricultural year, perceptions of risk were differentiated by seasonal water availability (Table 3). In the 'high-risk' kharif season characterised by uncertain rainfall, farmers made passive decisions, choosing similar sowing and cultivation patterns every year. Farmers across income groups, landholding size, and water availability categories, sowed the kharif crop irrespective of anticipated rainfall because they perceived having little control over rainfall and chose planting a kharif crop rather than risking food insecurity. For marginal farmers, total dependence on the kharif 
crop for food security meant they always chose to sow rather than not, in an attempt to harvest 'at least some maize'. Typically, the same crops were sown every year with minor adjustments.

The secondary rabi crop was more strategic because the farmer could control acreage, irrigation, and crop choice. Access to this additional water - a function of well ownership, access to common water resources, and irrigation infrastructure - defined whether rabi cultivation was high or low risk. Farmers who did not have access to wells chose crops like gram which require less water. Farmers with assured water availability did not perceive the rabi season as risky, grew wheat and gram, and even diversified into onions and seasonal vegetables.

Table 3 Seasonal factors affect risk perceptions and agricultural decisions: two illustrative cases

\begin{tabular}{|c|c|c|}
\hline & Kharif season & Rabi season \\
\hline \multirow{5}{*}{$\begin{array}{l}\text { Factors } \\
\text { affecting } \\
\text { decisions }\end{array}$} & Onset of rainy season & Residual soil moisture \\
\hline & Landholding size & Access to supplementary irrigation \\
\hline & Seed availability & Access to irrigation infrastructure (well, pipes, \\
\hline & Food requirements & pump, household labour) \\
\hline & Access to protective irrigation & Food requirements \\
\hline $\begin{array}{l}\text { Mohan (CS4) } \\
\text { (poor, } \\
\text { smallholder } \\
\text { tribal farmer) }\end{array}$ & $\begin{array}{l}\text { Reactive: 'As soon as it rains, I sow. There } \\
\text { is no decision to take. We assume the } \\
\text { rains will be normal when sowing crops. } \\
\text { Often we have bad dry spells. But that is } \\
\text { how it is.' }\end{array}$ & $\begin{array}{l}\text { Passive: 'In winter I leave my land fallow. If } \\
\text { there is some moisture, I grow gram. If the } \\
\text { rains last beyond Diwali (festival in October), I } \\
\text { grow wheat. In good years, I hire an engine } \\
\text { and water my land.' }\end{array}$ \\
\hline $\begin{array}{l}\text { Madhav (CS8) } \\
\text { (large } \\
\text { landholder, } \\
\text { upper caste } \\
\text { farmer) }\end{array}$ & $\begin{array}{l}\text { Reactive: 'In the rainy season, I grow } \\
\text { soybean and very little maize every year. } \\
\text { This does not change, as I cannot predict } \\
\text { the monsoon. Depending on the rains, my } \\
\text { crop ripens.' }\end{array}$ & $\begin{array}{l}\text { Proactive: 'In winter, I grow wheat and some } \\
\text { vegetables depending on water availability. I } \\
\text { decide how much wheat to grow based on my } \\
\text { experience and water in the well.' }\end{array}$ \\
\hline
\end{tabular}

Source: In-depth life histories

Beyond the immediate agricultural year, collectively constructed notions of risk, experiences of past events, and expectations of future variability shaped decisions. As Madhav (CS8), a prosperous Rajput farmer noted:

In the rainy season, soybean is the safest bet. There is no alternative to soybean. Crops like caraway are too dependent on the weather. And other crops do not have a market here.'

Here, Madhav alludes to an intuitive decision not to grow/experiment with other crops that are weather sensitive because of his perception that rainfall is too erratic to rely upon. Thus, even for a farmer without asset constraints, climate variability and water scarcity may narrow available cropping options. He hints at the lack of alternatives (no market for other crops) as a reason for 
staying with 'safe' crops like soybean. Such perceptions and their translation into behavioural action have crucial implications for policies aimed at increasing farmer uptake of new crops.

Decisions drew heavily on personal experience and continuous learning. The case of Mohan, previously introduced as a tribal smallholder (Box 1), illustrates this. Mohan grew soybean and maize in the kharif and gram, lentils, and wheat in the rabi season of the non-drought year 2010-11 (Figure 4). He also grew radish and fenugreek by water secured from his neighbour's well in exchange for fenugreek seed. However, since the forest bordered his land, the crop was damaged by monkeys and returns were poor.

Figure 4 Calendar of Mohan (CS4): agricultural and livelihood activities in 2010-2012 illustrating how experience shapes decisions

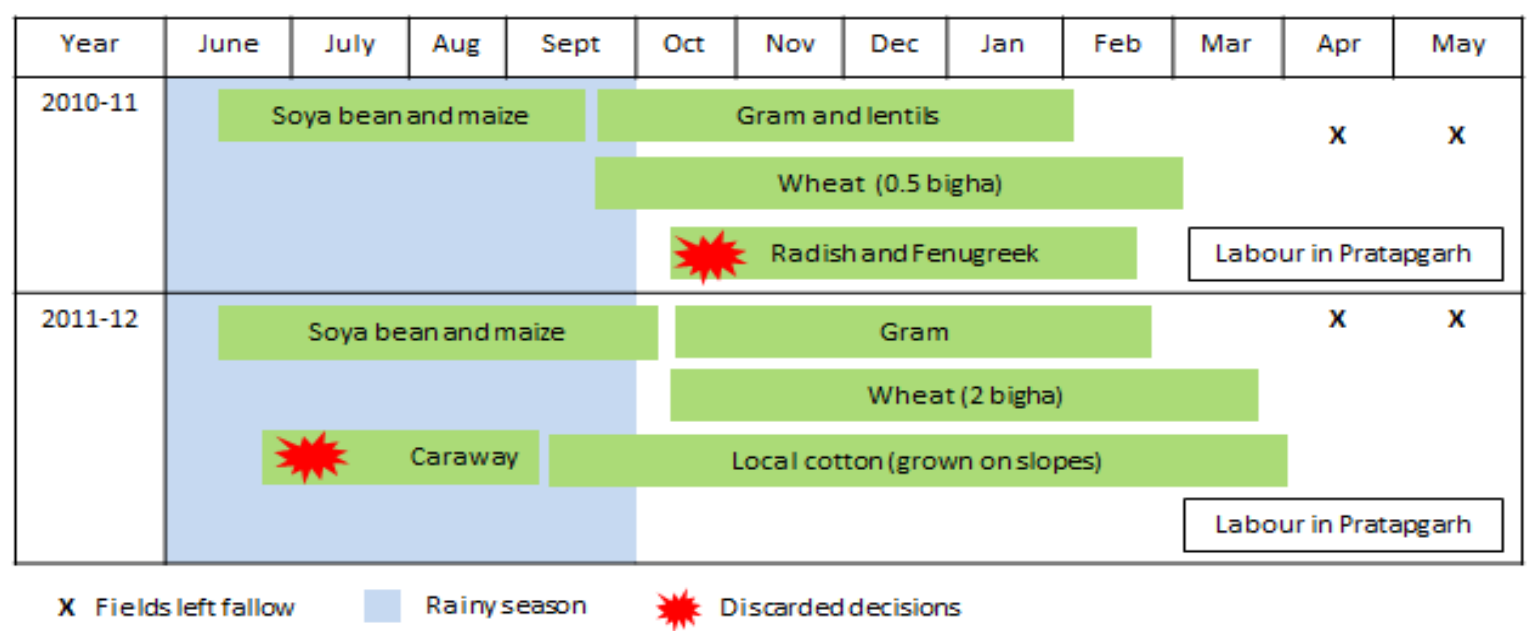

Source: In-depth interviews with Mohan and wife [CS4, 31.05.2012]

In 2011-12, Mohan grew soybean and maize in the kharif season, and expecting another good year, grew some caraway, which was made possible because his neighbour had procured caraway seed from Pratapgarh. However, 2011 saw particularly heavy rainfall $(1300 \mathrm{~mm}$ average annual rainfall against the usual $750-850 \mathrm{~mm}$ ) and washed away the caraway. Soybean and maize yields were reduced by half. Following these losses, Mohan stopped growing vegetables because he perceived it too risky. He also decided not to grow caraway because the seed was expensive and he could not afford another loss. The case illustrates how experiences of past performance inform crop choices, build baseline response capacity, and accumulate knowledge for future decisions. Therefore, although willing to experiment and diversify his crops, a resource-constrained farmer like Mohan cannot weather small losses, constricting his response space. 


\subsubsection{Asset constraints and interactions with other factors}

The household survey showed that poor asset ownership constrains agriculture: $25 \%$ farmers identified lack of inputs as the key constraint to agriculture, placing it above water scarcity and 53\% ranked lack of inputs second to water scarcity. This has implications for schemes such as distribution of free mustard and white chickpea seed by the Department of Agriculture. Without basic assets and financial safety nets to cope with short-term losses, provision of 'free' seed to resource-constrained farmers may be inappropriate.

Agricultural decisions were based on production factors (e.g. availability of water, seed, fertilisers), market-based factors (input costs, crop prices, credit availability), and factors intrinsic to households (i.e., characteristic of the household) such as asset ownership, demographic composition, and access to social networks. The interplay between extrinsic and intrinsic factors is discussed using two contrasting cases (Box 2) where agricultural decisions were considered for a year with typical annual average rainfall (2010-11) and a heavy rain year (2011-12), identified using weather data and corroborated by farmers. The two cases use the examples of a wealthy (CS1) and poorer (CS6) household to illustrate how resource access interacts with other factors to affect decisions.

The cases highlight that since Pratapgarh's farmers negotiate goals of food security and income generation within land and water constraints, access to protective irrigation is a crucial asset. While the kharif crop was sown according to monsoon onset, the rabi crop was sown based on soil moisture and well ownership/access. Access to irrigation infrastructure enabled Khemraj to experiment with and change crops. He could also grow wheat every winter, which fed his family for 4-5 months. In comparison, Ram grew gram in 2010-11 because of limited water availability and bought grain.

In both cases, crop choice depended on household food requirements followed by financial aspirations. While Khemraj managed to grow sufficient grain to feed his family throughout the year, Ram's family was food insecure for five months in a year, because poor water availability allowed him to grow only one food crop. 
Box 2 Agricultural calendars of Khemraj (CS1) and Ram (CS6) illustrating how physical and intangible asset constraints affect choices available to farmers

Khemraj (CS1, top calendar) grew soybean, caraway, and maize in the kharif (monsoon) and wheat in the rabi (winter) season. He used an NGO-led scheme to buy a pair of goats in 2011-12.

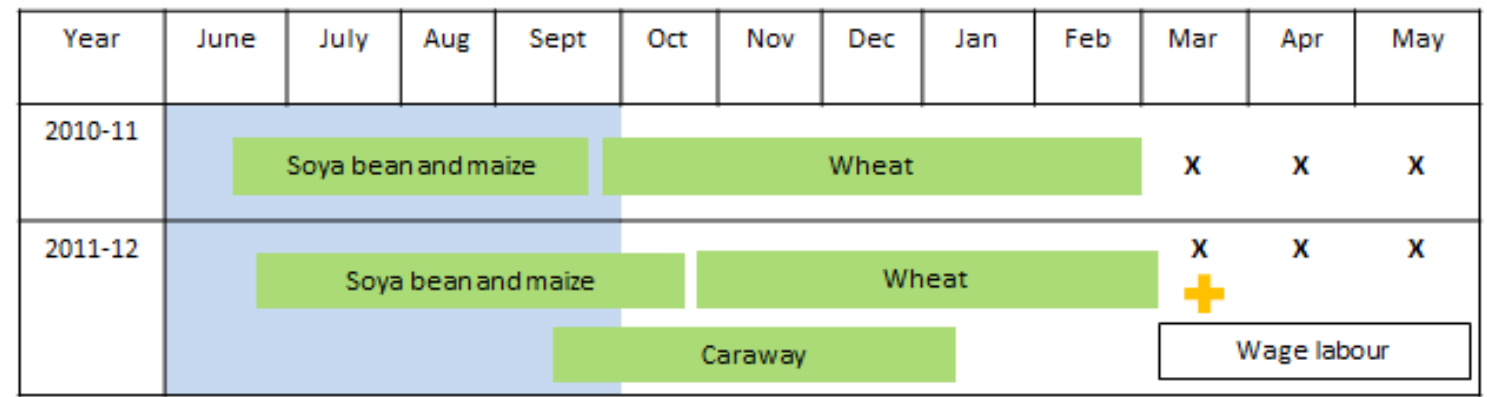

\begin{tabular}{|c|c|c|c|c|c|c|c|c|c|c|c|c|}
\hline Year & June & July & Aug & Sept & Oct & Nov & Dec & Jan & Feb & Mar & Apr & May \\
\hline \multirow{2}{*}{$2010-11$} & \multirow{2}{*}{\multicolumn{4}{|c|}{ Soya bean and maize }} & & & & & & & & \\
\hline & & & & & \multicolumn{4}{|c|}{ Gram } & $\mathrm{x}$ & $\mathrm{x}$ & $\mathrm{x}$ & $\mathrm{x}$ \\
\hline \multirow[t]{2}{*}{ 2011-12 } & \multirow{2}{*}{\multicolumn{4}{|c|}{ Soya bean and maize }} & $x$ & $x$ & $x$ & $x$ & $x$ & $x$ & $x$ & $x$ \\
\hline & & & & & & Labou & in Prat & ggarh & \multicolumn{4}{|c|}{ Seasonal migration (Udaipur) } \\
\hline
\end{tabular}

X Fields left fallow Rainy season $1 / 4$ Bought pair of Sirohi goats

Ram (CS6, bottom calendar) grew soybean and maize in the kharif (monsoon) and gram in the rabi (winter) season (because of lack of water for wheat) in both years. The torrential rains of 2011 flooded the local pond and destroyed Ram's mud hut. Unable to repay previous loans, he left his land fallow in the 2011 winter. With his wife and two teenage sons, Ram did labour work in neighbouring villages.

Source: Interviews with Khemraj, his wife and 2 children (May 2012), with Ram, and his wife (March 2012)

Both farmers adjusted their sowing in response to changes in monsoon onset. In 2010, soybean was planted early because rainfall started on $13^{\text {th }}$ June. In 2011 , the rains started on $26^{\text {th }}$ June, delaying soybean sowing. In 2010-11, the rains also stopped early (before $30^{\text {th }}$ September), and thus, both farmers harvested the kharif crop early and planted their rabi crop before the usual time of end October/early November. They chose to sow earlier to take advantage of residual soil moisture, necessary for winter crop germination.

Despite rainfall-related uncertainty, Khemraj (CS1) drew on his relationship with a local shopkeeper to buy caraway seed: 'I grew caraway for the first time this year. Since we had good rains, my father advised me to try it. Caraway can be very profitable - it gives INR7000/quintal (\$107.5) against INR2000/quintal (\$31) for soybean. My brothers and I cultivated caraway together. But untimely rains reduced yields. We will repeat it next year. If we get no profit again, we will stop.' This 
highlights how borrowed experience from elders and risk sharing by utilising the social capital of his brothers, allowed Khemraj to grow a weather-sensitive crop.

In both cases, decisions were more a reflection of real or perceived availability of different options and not a function of preferences. For example, Ram grew less soybean in 2011, not to manage risk from water scarcity or price fluctuation, but because he was unable to procure adequate seed. Contrastingly, timely availability of fertilisers and good quality seed helped Khemraj make profits in the good rain year of 2010-11. He used the extra money to buy a pair of Sirohi goats (a breed known for fast growth and disease resistance) through a local NGO he had successfully liaised with earlier. Ram's family, on the other hand, collected and sold non-timber forest products, which is a lowincome, labour-intensive activity earning only INR40-50/day (\$0.7).

Other cases demonstrated that changes in prices and market demand were not significant motivators for smallholder farmers with very limited access to resources. For example, small landholder (CS4) noted 'I don't have enough to sell in wholesale markets. I usually sell soybean in local shops to pay off previous bills', which was reflected in large landholders (CS8) as well: 'I keep a close watch on market prices and try to grow crops that have high demand. For example, I will invest in garlic this winter because of the price rise.' The ability to invest in new crops and absorb shortterm losses allowed large landholders to base decisions on market dynamics, the effects of which were seen in longer time periods (over 1-2 years) unlike drivers such as seed and water availability, which operate on seasonal scales.

The cases highlight that tangible asset constraints (e.g. water and seed unavailability) and intangible factors (advice from elders) interact to affect household decision-making. These factors may be intrinsic to households or driven by extrinsic drivers like provision of Sirohi goats by an NGO.

\subsubsection{The role of self-perception in pathway decisions}

Perceived capacity to perform a certain strategy and reach a particular outcome affected choice of strategy (Table 4). Individual characteristics like illiteracy, social exclusion, or feelings of inferiority affected perceived self-efficacy in carrying out an action and shaped final decisions.

Often, farmers avoided certain options because they perceived limits to their ability to achieve certain outcomes, leading to a failure of aspirations. Since aspirations are as much an act of setting 
goals as finding ways to achieve them (Appadurai 2004), failure to perceive oneself as able to reach these goals narrowed the bundle of strategies available to a household, especially in times of stress.

Table 4 Illustrative examples of perceptions of one's ability to act effectively affecting decisions

\begin{tabular}{|c|c|c|c|}
\hline \multirow{2}{*}{$\begin{array}{l}\text { Decision } \\
\text { made }\end{array}$} & \multicolumn{2}{|r|}{ Constraining factors } & \multirow[t]{2}{*}{ Farmer quotes } \\
\hline & Asset constraints & $\begin{array}{l}\text { Socio-cognitive } \\
\text { constraints }\end{array}$ & \\
\hline $\begin{array}{l}\text { Continuation } \\
\text { of old } \\
\text { livestock } \\
\text { feeding } \\
\text { patterns }\end{array}$ & $\begin{array}{l}\text { Insufficient } \\
\text { fodder }\end{array}$ & $\begin{array}{l}\text { Perceived inability to } \\
\text { put recommendations } \\
\text { by extension workers } \\
\text { into practice }\end{array}$ & $\begin{array}{l}\text { 'I go for trainings but cannot put their ideas } \\
\text { into practice. They tell us to mix nutrients in } \\
\text { fodder to increase milk output. I barely have } \\
\text { enough to feed the cow, how do I do this?' } \\
\text { [CS14] }\end{array}$ \\
\hline $\begin{array}{l}\text { Not to grow } \\
\text { mustard }\end{array}$ & $\begin{array}{l}\text { None. Seed } \\
\text { available from } \\
\text { government free } \\
\text { of cost }\end{array}$ & $\begin{array}{l}\text { Discomfort in } \\
\text { approaching } \\
\text { government extension } \\
\text { officer due to illiteracy }\end{array}$ & $\begin{array}{l}\text { 'I would like to grow mustard but I feel } \\
\text { uncomfortable going to the extension officer. } \\
\text { We have to sign there and I am illiterate. The } \\
\text { children laugh at me when I put my thumb } \\
\text { print.' [HH_Jh_13] }\end{array}$ \\
\hline $\begin{array}{l}\text { Not do } \\
\text { labour in } \\
\text { Pratapgarh } \\
\text { town }\end{array}$ & $\begin{array}{l}\text { Cost of travelling, } \\
\text { low social capital } \\
\text { in town. }\end{array}$ & $\begin{array}{l}\text { Unfamiliar } \\
\text { surroundings }\end{array}$ & $\begin{array}{l}\text { 'I do not go to town for labour because I do } \\
\text { not know anyone there. I have never gone } \\
\text { beyond my village.' [HH_K_126] }\end{array}$ \\
\hline
\end{tabular}

Differences in perceived adaptive capacity were noted between villages. In relatively socioeconomically homogenous communities, farmers improved their farming by learning from each other. In hamlets divided along caste, even poor Rajputs were perceived as being 'better off' than tribals because belonging to upper castes denoted privileges.

'I decided to grow cumin this year because I saw Govind growing it. He always does his farming well and I thought I can use his knowledge.' [HH_K_131]

'I cannot change anything because I don't have money. I am a tribal man, how can I ever be like the Rajputs? They have more land, more status.' [HH_Kh_81]

The first quote illustrates how demonstration by someone who is in a similar socio-economic context can motivate another farmer to act similarly. Seeing certain strategies 'work' for someone perceived as 'similar' (Govind) helped widen the respondent's aspirations and perceived self-efficacy. The second quote shows that from a tribal farmer's perspective, Rajput farmers are beyond his 'cognitive window' (Ray, 2006), i.e., the differences in their contexts are so unbridgeable, that they do not allow the tribal to emulate or learn from the Rajput farmer. 
Personal attributes of a farmer (optimistic versus pessimistic, forward thinking versus fatalistic) also play a role in perceived adaptive capacity and hence personal goals and aspirations. It is suggested that optimistic, forward-looking decision makers were more likely to make successful adaptation decisions as compared to more pessimistic farmers with a fatalistic attitude (see Table 6 for examples).

\subsubsection{Cognitive and normative influences on pathway decisions}

Actors external to households, such as other households, neighbouring villages, local shopkeepers, extension officers, and civil society workers influenced farmer decisions. Farmers complied with opinions by influential people (parents, neighbours, local leaders) perceived as 'acceptable' within the socio-cultural context. This drove response strategies considered 'appropriate' behaviour for a person belonging to that society, of that social standing, and religious and cultural affiliation.

Decisions moved from being rooted in traditional practices or insular to external influences, to being open to autonomous or reactive experimentation and external ideas (Table 5). Focus group discussions and key informant interviews highlighted how access to and channels of information, which are shaped by social networks and perceptions of self-efficacy, drove decisions. Availability and timing of information were crucial to uptake of new agricultural technologies. Even families with access to information were often unable to utilise it due to lack of relevant advice ('they tell us about plants grown in plains, but our land is undulating so we face erosion and runoff.' HH_HK_23), poor timing ('we get to know about heavy rains as they happen. There is no forecasting system.' HH_K_129), and mismatch between information and service delivery ('we were told that every farmer would get $2 \mathrm{~kg}$ maize seed but when we went to the office it was finished.' HH_Jh_6). This mismatch was mediated by users' perception of their self-efficacy and capacity, which is shaped by socio-cultural context and status.

Table 5 Differences in response decisions based on social networks and institutional linkages

\begin{tabular}{|c|c|c|}
\hline Type of influence & Farmer characteristics & Illustrative farmer quotes \\
\hline $\begin{array}{l}\text { Confer with } \\
\text { elders }\end{array}$ & $\begin{array}{l}\text { Stick to tradition, faith in } \\
\text { experience }\end{array}$ & $\begin{array}{l}\text { 'I grow same crops every year. It is better to stick with } \\
\text { what works; I can't go too wrong with them.' (CS7) }\end{array}$ \\
\hline $\begin{array}{l}\text { 'Only option } \\
\text { available' }\end{array}$ & $\begin{array}{l}\text { Low perceived self-efficacy, } \\
\text { poor social networks within and } \\
\text { outside the community, } \\
\text { fatalistic attitude }\end{array}$ & $\begin{array}{l}\text { We do what we have been doing every year depending } \\
\text { on available seed and water. We do not have the } \\
\text { money to make changes. I want to change the crops I } \\
\text { grow, but there is no option. [HH_Jh_30] }\end{array}$ \\
\hline $\begin{array}{l}\text { 'It is the best } \\
\text { option available' }\end{array}$ & $\begin{array}{l}\text { Low perceived self-efficacy, } \\
\text { fatalistic attitude and mind-set } \\
\text { of 'making do' }\end{array}$ & $\begin{array}{l}\text { I grow soybean because it is the best option. Rainfall is } \\
\text { unpredictable and we must grow something to survive. } \\
\text { All other crops give lesser return. [HH_K_109] }\end{array}$ \\
\hline
\end{tabular}




\begin{tabular}{lll}
\hline $\begin{array}{l}\text { Autonomous } \\
\text { experimentation }\end{array}$ & $\begin{array}{l}\text { Open to experimentation, } \\
\text { medium perceived self-efficacy, } \\
\text { uses social capital to explore } \\
\text { options }\end{array}$ & $\begin{array}{l}\text { I am growing wheat, lentils and cumin this winter. I } \\
\text { usually do gram but this year I have tried something } \\
\text { new. I heard it gives better returns. [HH_NA_11] }\end{array}$ \\
\hline $\begin{array}{l}\text { Externally driven } \\
\text { experimentation }\end{array}$ & $\begin{array}{l}\text { Experimentation, as a response } \\
\text { to stressors }\end{array}$ & $\begin{array}{l}\text { This is the first time we are growing garlic. Rats spoil } \\
\text { wheat so we switched to garlic this year. If I get good } \\
\text { returns, I will stop growing wheat. [HH_Kh_74] }\end{array}$ \\
\hline $\begin{array}{l}\text { Externally aided } \\
\text { experimentation } \\
\text { (drawing from } \\
\text { what others do) }\end{array}$ & $\begin{array}{l}\text { Experimentation as an } \\
\text { autonomous proactive strategy, } \\
\text { uailises social networks to learn, } \\
\text { and adopts when proven }\end{array}$ & $\begin{array}{l}\text { Richer farmers are always experimenting and growing } \\
\text { different crops like flax. I learn more from them than } \\
\text { trainings by the Agriculture Department. I have more } \\
\text { faith in something I see with my own eyes. [CS3] }\end{array}$ \\
\hline & $\begin{array}{l}\text { Open to new strategies when } \\
\text { aided by external actors, } \\
\text { proactive and aspiring to better } \\
\text { one's condition }\end{array}$ & $\begin{array}{l}\text { In 2005, a private company gave me JS335 soybean } \\
\text { seed to try. It is of uniform height, ripens together, and } \\
\text { is high yielding. So I saved the seed and grow it every } \\
\text { year now. I also sell it to other farmers. [CS1] }\end{array}$ \\
\hline
\end{tabular}

Neighbours, elders, and informal institutions were important sources of information to base agricultural decisions on. Farmers with strong social capital and past experience of positive outcomes from better information actively sought it by exploiting social connections with shopkeepers, agriculture officers, and local NGO workers. Support from external actors was received differently by different farmers: resource-constrained farmers perceived themselves as 'receivers' of government aid and did not consider themselves agents of change while farmers with assets actively pursued all available alternatives. This differential perception of self-efficacy and capacity to act shaped pathway decisions.

Local shopkeepers doubled as buyers of local produce, seed dealers, moneylenders and sources of information on pest control, fertilizer dosage, market prices and weather forecasts. Since farmers relied on shopkeepers for multiple needs that spanned beyond farming, they cultivated these relations with care, making sure borrowing was within socially acceptable limits, altercations were amicably resolved, and relationships were lubricated by regular interactions. Regular loan defaulters or farmers not adhering to social norms, were not favoured by shopkeepers. Thus, by the information and control they held, shopkeepers exercised significant influence on farmers' decision pathways.

Information access was generally male-dominated with women having negligible access to information channels since spaces such as markets and village meetings were differently accessed by 
men and women. This was pertinent for female-headed households who depended on neighbours or experience to make farm decisions.

\subsection{How do farmers choose?}

Typologies can help to understand how farmers' decisions are made and what characterises this process. Based on the case study results, three farmer 'types' are identified (Table 6), moving from a closed, fatalistic attitude (top) to a more open, experimental attitude (bottom).

Table 6 Farmer typology based on their responses to stress

\begin{tabular}{|c|c|c|}
\hline Farmer 'type' & Characteristics & Illustrative famer quotes \\
\hline $\begin{array}{l}\text { The fatalistic } \\
\text { farmer }\end{array}$ & $\begin{array}{l}\text { 'No response' because of perceived inability } \\
\text { to change one's situation. Strong belief in } \\
\text { external stressors as 'act of God'. Meagre } \\
\text { asset base and social marginalisation } \\
\text { discourage proactive responses. Unable to } \\
\text { envision improvements in the future. }\end{array}$ & $\begin{array}{l}\text { 'We can't do anything in drought years. We } \\
\text { don't have any choice and decisions are } \\
\text { made for us 'automatically' depending on } \\
\text { the rainfall that year.' [CS4] }\end{array}$ \\
\hline $\begin{array}{l}\text { The passive } \\
\text { farmer }\end{array}$ & $\begin{array}{l}\text { Makes decisions to stay 'afloat'. Instinctive } \\
\text { decision-making based on experience. Passive } \\
\text { decisions using last resort strategies. }\end{array}$ & $\begin{array}{l}\text { 'I know what we have to grow so no need to } \\
\text { plan. It is the same every year. I grow crops } \\
\text { based on past experience and food } \\
\text { requirements.' [CS11] }\end{array}$ \\
\hline $\begin{array}{l}\text { Purposive, } \\
\text { forward-looking } \\
\text { farmer }\end{array}$ & $\begin{array}{l}\text { Continual evaluation of current and future } \\
\text { situation, iterative decision-making with } \\
\text { learning. Estimate short-term assets and } \\
\text { calculate longer-term asset flows and future } \\
\text { costs of choosing a certain strategy. Continual } \\
\text { re-evaluation of goals to make trade-off } \\
\text { decisions. Takes advantage of social } \\
\text { networks, links with external actors to make } \\
\text { decisions. }\end{array}$ & $\begin{array}{l}\text { 'I mix long-term strategies (digging well) } \\
\text { and short-term strategies (growing lentils). } \\
\text { During kharif, one can change physical } \\
\text { resources like crop type, seed quality, and } \\
\text { fertiliser. In winter, arranging adequate } \\
\text { water is necessary. I realised that if I farmed } \\
\text { like my father, I would get nowhere. So I } \\
\text { became more active.' [CS1] }\end{array}$ \\
\hline
\end{tabular}

Source: In-depth life histories

Farmers open to experimentation and learning took ideas from various actors, widening the pool of available options to try and agricultural models to aspire to. Risk perception drove behaviour and personal thresholds and levels of acceptable risk, individuals chose some risk-minimisation strategy. Resource-constrained farmers (CS4, CS6) were fatalistic, while purposive decision makers (CS1, CS14) had stronger asset bases financial safety nets, and social networks to tap into.

Farmers chose a response based on its potential 'cost' to the household. Better response strategies had lower financial, social, and environmental costs. Often, minimising cost on one facet emphasised another and relative weights given to these costs varied among households. For example, CS4 reported investing in goats as an asset to sell when in need of quick cash. However, the trade-off of this benefit was additional time for grazing. In contrast, a female-headed household (CS10) chose 
not to keep livestock because the time spent tending to goats was not seen as an 'adequate' benefit. Instead, she worked as agricultural labour during harvest season. Thus, households continuously juggle between options and objectives, adjusting risk management strategies proactively (through goat rearing) or reactively (wage labour). Purposive decision makers (CS1, CS14) met their food and income goals without substantial trade-offs, while passive households undertook maladaptive responses (children dropping out of school, pawning jewellery) during crises.

\section{A typology of response pathways and adaptation decision-making}

Drawing from previous sections on factors that drive household decision-making based on 14 farmer life histories, we present an approach to chart household trajectories (Figure 5) and present how these factors interact to result in different response pathways. Although illustrative in nature, it provides a starting point to understand differences in household and intra-household response trajectories. Responses are placed with respect to two boundaries: (1) ecological boundaries beyond which ecosystem flows and services will be compromised (Rockstrom et al., 2009); (2) a social foundation denoting minimum requirements to ensure human survival, security, and self-respect (Leach et al., 2013). Thus, adaptive pathways are those that stay within the ecological ceiling while meeting social needs; coping strategies barely meet social needs and (potential) maldaptive responses breach the ecological ceiling.

Figure 5 Households take different response pathways. Some do not meet basic standards of well-being (A); some overcome chronic poverty but remain close to destitution (B); others achieve a higher standard of living but may move towards the upper environmental limit (C). Pathway $D$ is a hypothesised pathway.

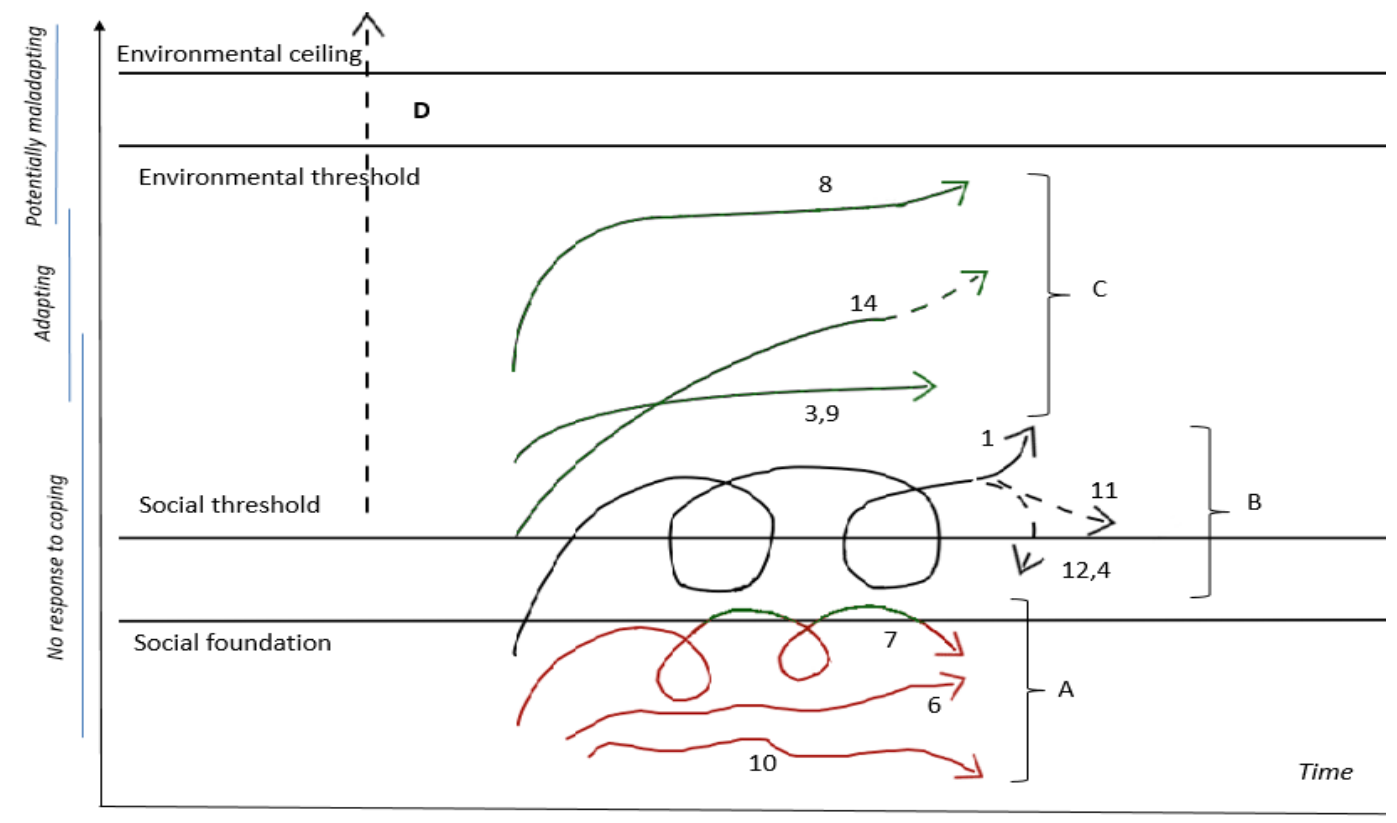


Crucially, each household starts from a different place and takes different trajectories based on the decisions they make (which we have shown are based on perceived risk, available resources, external institutions and actors which may be supportive or erosive conditions, household composition and dynamics (e.g. gender of household head), and perceived ability to adapt. The approach shows that examining and comparing different decision pathways help understand why some households adapt while others fail to. Importantly, since the pathways change temporally, a household cannot be termed as 'having adapted'. Specific trajectories are discussed next.

\section{Pathway A: Resource-constrained, tribal households that are usually women-headed are barely} able to cope: CS6 and CS10 are tribal households headed by women who are widows. CS6 has access to wage labour through an NGO-led watershed project in her village. She is also well-connected to the village head and gets support from him for farming, marketing and accessing social security schemes. CS10 is 75 years old and has no family except a young grandchild. Resource constraints and household demography do not allow her to make changes and one observes reduction in well-being over time. Male-headed household (CS7) also starts from a similar situation but is able to somewhat improve its condition by taking loans from moneylenders. However, this is not financially sustainable and CS7 moves in and out of poverty.

Pathway B: Perceived adaptive capacity and personal approach define response pathway: This set of tribal farmers start from a similar situation of minimum survival. They are resource poor but are not constrained to a level of chronic or absolute poverty. CS1 follows a trajectory of trial and error, with downward spirals when drought years or idiosyncratic shocks affected household well-being negatively. Experimentation, proactive decision-making and exploitation of the environmental, socio-economic, and institutional landscape helped CS1 move towards higher well-being. CS11 takes decisions based on experience and traditional knowledge and relies on informal information networks rather than external agents. Though currently managing in a safe operating space, existing knowledge systems may not provide suitable solutions in the face of increasing climate variability, which may lead the household into lowered well-being (dotted downward line). CS12 and CS4 are risk-averse farmers who have poor social capital and low perceived adaptive capacity, making them more sensitive to environmental and socio-economic changes and thus more likely to slip below the social foundation.

\section{Pathway C: Resource-rich farmers are gravitating towards ecologically unsustainable pathways:}

This group denotes a range of households: those charting steep material growth (CS14), those maintaining status quo by a mix of coping and adaptive strategies (CS3 and CS9), and wealthier, proactive households that are approaching the environmental threshold (CS8). Diversifying into non- 
farm activities (CS9 opened a local shop) reduces household sensitivity to risk associated with agriculture and income from the shop has enabled CS9 to invest in farming. With the help of a willing and educated spouse, CS9 has been able to realise his ambitions, highlighting that collective decision-making and dialogue between household members is conducive to household adaptation.

CS14 shows rapid improvement in well-being by proactive decision-making and nurturing social networks. He has taken risks, emulated other successful farmers, and sought information and help from external actors. CS8 portrays a typical upper-caste, relatively resource-rich household who has maintained a relatively higher standard of living. However, in the face of increased climate variability and resource degradation (lowered soil fertility, groundwater depletion), he has adapted by buying sprinklers, diversifying crops and sources of income. Financial assets, social capital, and education have allowed CS8 to continue grow water-intensive crops like garlic. While this has achieved personal prosperity, it may be the cost of ecological sustainability.

\section{(Hypothesised) Pathway D: Current dependence on resource-intensive crops may breach the}

environmental ceiling: This unsustainable pathway is a hypothesised insight and was not observed, primarily because agriculture in Pratapgarh is still subsistence-based. So far, crossing critical ecological thresholds have to some extent be avoided by (1) most farmers taking a single crop per year and (2) natural resource management efforts by local NGOs and the state forest department. However, current trends of decreasing soil fertility and loss in forest cover (FES, 2009), lowering groundwater levels (CGWB, 2007), potential pressures of an increasing population (Pratapgarh NIC, 2012), and increasing climate variability (Singh, 2014) might nudge farmers like CS8 and CS14 on this pathway.

The four pathways indicate that farmers 'continuously re-interpret the contexts in which they move' (Klerkx 2010:390) through coping, adapting and innovating and that within the same biogeographical and social context; different households undertake different response strategies and thus follow different trajectories. These trajectories themselves are dynamic and climatic or idiosyncratic changes may introduce further uncertainty as to how households move along, negotiating their social well-being, intrinsic resource constraints and inherent environmental boundaries. The chief challenge for current initiatives aimed at building local capacity is incorporating these dynamics. 


\section{Discussion}

The following sections explore three areas identified as important in the findings above: the decision-making process and added-value of a holistic approach; the key role of socio-cognitive factors to adaptation; and reflections about the ways in which smallholder farmers are characterised, which has relevancy for policy and practice.

\subsection{The decision-making process}

Farmers used a bundle of response strategies either singly or in tandem, and these were differentiated by timing (certain strategies being undertaken at certain points in the agricultural cycle), duration of strategy (short-term coping to long-term adapting), and the family member performing it (young versus old members, men versus women). Inter-household differences in responses were based on intrinsic household attributes (baseline resilience, demographic composition, and socio-economic status), and extrinsic factors (natural resource dependence, market fluctuations and access to information). Even in good years, farmers depended on non-farm labour because they perceived agriculture as inherently risky and insufficient to meet their needs. This uncertainty associated with farming affected perceived adaptive capacity and reduced farmer incentives to invest in agriculture.

Decision-making was iterative, with constant adjustments to match socio-ecological changes households are embedded in. Decision-making was passive in the kharif season and proactive in the rabi season, which has implications for promoting adaptive behaviour. If farmers only make proactive decisions in situations they feel in control of, perhaps more emphasis should be given to socio-cognitive aspects of decision-making as well as resource-related factors. Forward-looking farmers (Table 6) are proactive in both seasons because they perceive themselves as able to change the outcome of their action. Proactive farmers follow weather forecasts, tried sourcing early maturing varieties, and organised supplementary water resources based on their belief that they have the capacity to change the outcome of the kharif season.

Men were chief decision makers in agriculture. Although women family members were consulted, it did not necessarily lead to incorporation of their opinions (Section 4.2). This relatively low participation stemmed from their differential bargaining power depending on their position within the household and larger community. Women's decision-making was also truncated by poor access to information, and lower interaction with external actors. These culturally-shaped restrictions meant that women, especially those of upper caste Rajput households, seldom interacted with extension agents or shopkeepers and traders, constricting the space they participated in. Gendered 
differences also interact with other social identities such as caste, age and income (Ahmed and Fajber, 2009); older women had more intra-household bargaining power, and tribal women interacted with shopkeepers more freely than their Rajput counterparts. Interestingly, Rajput women reported feeling secure in existing gendered roles (within their households) and a sense of superiority over tribal women who were perceived as uncivilised because they worked on farms and sold produce in the market. However, poor Rajput women often behaved like tribal women because they could not maintain socially constructed and accepted behavioural norms.

The life histories demonstrated that at the intra-household scale, households that allowed consultative decision-making (CS1) pursued a wider range of responses and had a strong learning component in their decision-making. Households with heads who were either very old (CS2) or had poor access to information (CS4), usually repeated decisions with minor adjustments. Such farmers were less likely to experiment in the face of changing climatic and socio-economic conditions. However, households with very young heads (CS7) were not necessarily open to change and illformed social safety nets. As shown in CS7, young farmers tended to be risk averse because of their lack of experience, poor asset base and under-developed social networks. Households with middleaged, educated heads (CS3) or strong social capital through extended families (CS5) were forwardlooking and open to experimentation. Such families made adaptive decisions because of higher assets, better networks with external actors, and familiar channels of credit access.

How decisions were taken was also important to the behavioural outcome. Where decision-making was consultative and participatory (CS1, CS3), responses incorporated agricultural and domestic needs simultaneously. Decisions made through dialogue were more inclusive and made costeffective trade-offs between competing goals.

\subsection{Socio-cognitive factors shape adaptation decision-making}

It is well-recognised that adaptation decision-making is based on perceptions of risk and an evaluation of one's capability to avert losses (Grothmann and Patt, 2005; Kroemker and Mosler, 2002). This perceived adaptive capacity determines whether adaptive behaviour will be carried out or not (Weber, 2010). Differential institutional entitlements and social roles (Kromeker and Mosler, 2002), social influence (Martínez-García et al., 2013), limited resources, and meeting short-term survival needs over longer-term goals (O'Brien, 2009) affect response decisions. Furthermore, intentions are often not realised because of the lack of objective adaptive capacity or the financial, social, or institutional resources to carry out an adaptation (Grothman and Patt, 2005). 
Evidence from Pratapgarh adds to this literature by demonstrating that behavioural actions are not only a function of socio-economic variables and asset ownership (Section 4.3.2) but also dependent on socio-cognitive factors like perceived risk, perceived ability to act, and personal motivations (Section 4.3.3); social influence and normative sanction; and information access and institutional linkages (Section 4.3.4). For example, tribal households with few resources and institutionalised histories of marginalisation reported perceptions of inferiority and hence low perceived ability to use available opportunities and engage in effective coping responses (for examples, see Table 4).

This findings contributes to research that discusses CCA decision-making as a function of intraindividual parameters and processes such as situation appraisal; cognitive analysis and emotion regulation; and extra-individual social situations such as social construction, sense making, and risk amplification (Reser and Swim, 2011). Further, since self-identity mediates adaptive choices (Frank et al., 2011), socio-cognitive factors interact with asset and information constraints to result in different decision pathways and hence different response trajectories. Thus, embedded in the same context, some farmers use their assets and social networks to make proactive decisions while others may take passive decisions relying on experience and choices perceived 'safe'.

The integrated approach has helped explore how these socio-cognitive factors are situated in wider pathways of livelihood change. These pathways are shaped by household members' interactions with multiple actors and can lead to strikingly different outcomes and adaptive ability.

\subsection{Challenging the passive victim narrative}

The three farmer typologies (Table 6) demonstrate that blanket characterisations of rural households as passive 'victims' of climatic or socio-political change are erroneous. Each household's response capacity allows it to respond actively or passively within the available response space and households take different trajectories based on their aspirations, assets, perceived adaptive capacity, intra-household dynamics, and inter-household networks (Section 5). Also, decision-making and response behaviour is not fixed: proactive farmers may behave reactively in certain situations and passive farmers may take proactive decisions in certain crises. This is demonstrated in Figure 5 where some households follow adaptive pathways that meet social needs within environmental thresholds and some spiral downwards to move in and out of chronic poverty. The research highlights that one cannot apply descriptors such as proactive and reactive across the board and these change over time and response to changes in the socio-cultural, economic and institutional landscape. 
The research reinforces previous findings that past exposure to external stressors helps people develop experiential knowledge about what responses work (Grothmann and Patt, 2005). However, experience of exposure may not be sufficient in the face of accelerated climatic change. Frequent exposure to high-intensity change can erode physical and intangible assets. Thus, we find that even previously 'successful' households may be unable to cope, accentuating vulnerability (e.g. Pathway D in Figure 5). A key finding is that perception of one's ability to act shapes capacity to respond. Indeed, farmer response strategies in Pratapgarh were predominantly 'fixed' (Jones et al., 2013:15), with few tribal farmers undertaking flexible, adaptive and forward-looking strategies. This has serious implications for the sensitivity of the current agricultural system to increasing climate variability and requires more attention by policy makers.

We also note that in the face of multiple stressors, farmers in Pratapgarh are shifting towards potentially maladaptive livelihoods that erode natural resources (Figure 5). These practices (inputintensive agriculture) can be seen as adaptive at a household scale because of increases in income, improved ability to invest in education and food but can potentially be maladaptive at wider scales and across time. Overall, although most farmers were not passive victims (Table 6, Figure 5), they are unable to undertake active adaptive change (defined as meeting social needs without breaching environmental thresholds (Section 5). We find that apart from a few proactive farmers, most are either maintaining status quo or moving in and out of vulnerability (Figure 5).

\section{Conclusion}

This paper developed and applied a set of framing questions together with key insights drawn from relevant literature, to investigate smallholder decision-making in an area of India. Key questions were identified about decision-making through different response pathways that can be applied in a range of locations and contexts. In the context of Rajasthan, selected as a representative example where smallholder farmers are facing multiple livelihood challenges, the approach found useful insights that have relevance for policy, research and practice and could be applied more widely in developing countries.

Reflecting on the methodology, we find that the approach enabled holistic, organised, and systematic engagement with the complex nature of farmer decision-making and helps focus attention on the process of response. Researching the processes enables a deeper understanding of (1) the varied and dynamic nature of household response pathways as a function of their assets, 
aspirations and actions, and (2) the constraints and appropriate entry points to support local adaptation.

The findings confirm the complexity of factors influencing decision-making. However, the response pathways approach helps make sense of this and provided a mechanism for interdisciplinary analysis. The findings explain why, despite targeted policy interventions, tribal smallholders cannot break away from their history of social marginalisation to make more proactive adaptation decisions. In addition, the paper highlights the mediating role of socio-cognitive factors in the decision-making process. For example, notions of inferiority among tribal farmers affected their perceptions of their capacity to access resources to manage risk (e.g. get subsidised pesticide), which in turn constrained their response action (saving crops from pest attack). The approach used in this paper can address these challenges by helping to understand the underlying issues and consider more inclusive policy interventions. This is not normally achieved by studies that take a single disciplinary perspective, while policy does not always recognise underlying reasons driving the inability to respond. In conclusion, the framing questions and approach help identify the entry points required to initiate an enabling environment that supports farmers to make adaptive choices.

\section{References}

1. Adams, A.M., Cekan, J. \& Sauerborn, R. (1998). Towards a Conceptual Framework of Household Coping: Reflections from Rural West Africa. Africa, 68(2), 263-283. DOI:10.2307/1161281

2. Adger, W.N. (2003). Social capital, collective action, and adaptation to climate change. Economic Geography, 79(4), 387-404. DOI: 10.1111/j.1944-8287.2003.tb00220.x

3. Adger, W. N., Huq, S., Brown, K., Hulme, M., \& Conway, D. (2003). Adaptation to climate change in the developing world. Progress in Development Studies, 3(3), 179-195. DOI:10.1191/1464993403ps060oa

4. Adger, W. N., Dessai, S., Goulden, M., Hulme, M., Lorenzoni, I., Nelson, D. R., Naess, L. O., Wolf, J. \& Wreford, A. (2009). Are there social limits to adaptation to climate change? Climatic Change, 93(3), 335-354. DOI:10.1007/s10584-008-9520-z

5. Agarwal, B., 1997. Bargaining and Gender Relations: Within and Beyond the Household. Feminist Economics, 3(1), 1-51. DOI:10.1080/135457097338799

6. Ahmed, S. \& Fajber, E. 2009. Engendering adaptation to climate variability in Gujarat, India. Gender and Development, 17(1), 33-50. DOI: 10.1080/13552070802696896 
7. Ajzen, I., Sparks, P. \& Hall, T. (2002). Perceived Behavioral Control, Self-Efficacy, Locus of Control, and the Theory of Planned Behavior. Journal of Applied Social Psychology, 32(4), 665-683. DOI: 10.1111/j.1559-1816.2002.tb00236.x

8. Appadurai, A. (2004). The Capacity to Aspire: Culture and the Terms of Recognition. In Rao, V., \& Walton, M. (Eds.), Culture and Public Action (59-84). Palo Alto, CA: Stanford University Press.

9. Armitage, C.J. \& Conner, M. (2001). Efficacy of the Theory of Planned Behaviour: A meta analytic review. British Journal of Social Psychology, 40(4), 471-499. DOI:

$10.1348 / 014466601164939$

10. Bagchi, D. K., Blaikie, P., Cameron, J., Chattopadhyay, M., Gyawali, N., \& Seddon, D. (1998). Conceptual and methodological challenges in the study of livelihood trajectories: casestudies in Eastern India and Western Nepal. Journal of International Development, 10(4), 453-468.

11. Barlett, P. F. (1980). Cost-benefit analysis: a test of alternative methodologies. In Barlett, P.F. (Ed.) Agricultural decision making. Anthropological contributions to rural development (137160). London, Academic Press Inc.

12. Bebbington, A. (1999). Capitals and Capabilities: A Framework for Analyzing Peasant Viability, Rural Livelihoods and Poverty. World Development, 27(12), 2021-2044. http://dx.doi.org/10.1016/S0305-750X(99)00104-7

13. Brehmer, B. (1990). Strategies in real time, dynamic decision making. In Hogarth, R.M. (Ed.), Insights in Decision Making: A tribute to Hillel J. Einhorn. Chicago, University of Chicago Press.

14. CAZRI. (2011). Central Arid Zone Research Institute, Jodhpur, Rajasthan (INDIA). Retrieved from http://www.cazri.res.in/

15. Chant, S. (2003). Female household headship and the feminisation of poverty: facts, fictions and forward strategies. New Working Paper Series, Issue 9. Gender Institute, London School of Economics and Political Science, London, UK. (Unpublished)

16. Dalton, P. S., Ghosal, S., \& Mani, A. (2015). Poverty and aspirations failure. The Economic Journal, 128 (February) 165-188.

17. Dorward, P.T., Shepherd, D. \& Wolmer, W. (1997). Developing farm management type methods for participatory needs assessment. Agricultural Systems, 55(2): 239-256. doi: 10.1016/S0308-521X(97)00009-7 
18. Frank, E., Eakin H., Lopez-Carr, D. (2011). Social identity, perception and motivation in adaptation to climate risk in the coffee sector of Chiapas, Mexico. Global Environmental Change, 21 (66-76). http://dx.doi.org/10.1016/j.gloenvcha.2010.11.001

19. Foundation for Ecological Security (FES), (2009). Common Land and Poor Livestockkeepers: Experiences from Common Land Development in the States of Rajasthan and Madhya Pradesh in India. Retrieved from http://fes.org.in/studies/10.pdf

20. Gbetibouo, G. (2009). Understanding farmers' perceptions and adaptations to climate change and variability: The case of the Limpopo Basin, South Africa. International Food Policy Research Institute (IFPRI).

21. Ghosal, S (2013). Lack of aspirations as a poverty trap. Blog on Ideas for India, 10 June, 2013. http://ideasforindia.in/article.aspx?article id=151

22. Gifford, R. (2011). The dragons of inaction: psychological barriers that limit climate change mitigation and adaptation. The American Psychologist, 66(4), 290-302. doi:10.1037/a0023566

23. Government of Rajasthan (2011). Rajasthan State Action Plan on Climate Change. Retrieved from http://www.indiaenvironmentportal.org.in/files/file/ClimateChange-rajasthan.PDF

24. Goyal, R.K. (2004). Sensitivity of evapotranspiration to global warming: a case study of arid zone of Rajasthan (India). Agricultural Water Management, 69(1), 1-11. doi: 10.1016/j.agwat.2004.03.014

25. Grothmann, T., Grecksch, K., Winges, M., \& Siebenhüner, B. (2013). Assessing institutional capacities to adapt to climate change: integrating psychological dimensions in the Adaptive Capacity Wheel. Natural Hazards and Earth System Science, 13(12), 3369-3384. doi:10.5194/nhess-13-3369-2013

26. Grothmann, T. \& Patt, A. (2005). Adaptive capacity and human cognition: The process of individual adaptation to climate change. Global Environmental Change, 15(3), 199-213. doi: 10.1016/j.gloenvcha.2005.01.002

27. Jain, M., Naeem, S., Orlove, B., Modi, V., \& DeFries, R. S. (2015). Understanding the causes and consequences of differential decision-making in adaptation research: Adapting to a delayed monsoon onset in Gujarat, India. Global Environmental Change, 31, 98-109. http://dx.doi.org/10.1016/i.gloenvcha.2014.12.008

28. Jones, L. \& Boyd, E. (2011). Exploring social barriers to adaptation: Insights from Western Nepal. Global Environmental Change, 21(4), 1262-1274. doi:

10.1016/j.gloenvcha.2011.06.002 
29. Jones, L., Jaspars, S., Pavanello, S., Ludi, E., Slater, R., Arnall, A., Ludi, Eva, Grist, N., Panvanello, S., Mtisi, S. (2010). Responding to a changing climate: Exploring how disaster risk reduction, social protection and livelihoods approaches promote features of adaptive capacity. ODI Working Paper 319. Retrieved from http://www.odi.org/sites/odi.org.uk/files/odi-assets/publications-opinion-files/5860.pdf

30. Jones, L., Ludi, E., Beautement, P., Broenner, C., \& Bachofen, C. (2013). New Approaches to Promoting Flexible and Forward-Looking Decision Making: Insights from Complexity Science, Climate Change Adaptation and "Serious Gaming". ODI, London. Retrieved from http://www.odi.org/sites/odi.org.uk/files/odi-assets/publications-opinion-files/8259.pdf

31. Kahan, D. (2008). Managing Risk in Farming. Food and Agriculture Organization (FAO), Rome. Retrieved from http://www.fao.org/uploads/media/3-ManagingRiskInternLores.pdf

32. Klerkx, L., Aarts, N., \& Leeuwis, C. (2010). Adaptive management in agricultural innovation systems: The interactions between innovation networks and their environment. Agricultural Systems, 103(6), 390-400.

33. Kroemker, D. \& Mosler, H.J. (2002). Human Vulnerability-Factors Influencing the Implementation of Prevention and Protection Measures: An Agent Based Approach in Steininger, K. \& Weck-Hannemann, H. (Eds.). Global Environmental Change in Alpine Regions. Impact, Recognition, Adaptation, and Mitigation. Edward Elgar, Cheltenham 95114.

34. Lambrou, Y., \& Nelson, S. (2010). Farmers in a Changing Climate: Does gender matter. Food Security in Andhra Pradesh. Food and Agriculture Organization (FAO), Rome. Retrieved from http://www.fao.org/docrep/013/i1721e/i1721e.pdf

35. Leach, M., Raworth, K., \& Rockström, J. (2013). Between social and planetary boundaries: navigating pathways in the safe and just space for humanity. World Social Science Report, 2013, 84-89.

36. Maddison, D. J. (2007). The perception of and adaptation to climate change in Africa. World Bank Policy Research Working Paper No. 4308.

37. Mall, R.K., Singh., R., Gupta, A., Srinivasan, G. \& Rathore, L. S. (2006). Impact of Climate Change on Indian Agriculture: A Review. Climatic Change, 78(2-4), 445-478. http://dx.doi.org/10.1007/s10584-006-9236-x.

38. Marfo, K.A., Dorward, P.T., Craufurd, P.Q., Ansere-bioh, F., Haleegoah, J., \& Bam., R. (2008). Identifying seed uptake pathways: the spread of Agya amoah rice cultivar in southwestern Ghana. Experimental Agriculture, 44, 257-269. doi:10.1017/S0014479708006170 
39. Martínez-García, C.G. Dorward, P., Rehman, T. (2013). Factors influencing adoption of improved grassland management by small-scale dairy farmers in central Mexico and the implications for future research on smallholder adoption in developing countries. Livestock Science, 152, 228-238. doi:10.1016/j.livsci.2012.10.007

40. Mintzberg, H., Raisinghani, D. \& Théorêt, A. (1976). The Structure of "Unstructured" Decision Processes. Administrative Science Quarterly, 21 (2), 246-275.

41. O'Brien, K.L. (2009). Do values subjectively define the limits to climate change adaptation? In W. N. Adger, I. Lorenzoni, \& K. O'Brien (Eds.) Adapting to Climate Change: Thresholds, Values, Governance. Cambridge University Press, 164-180.

42. Osbahr, H., Dorward, P., Stern, R., \& Cooper, S. (2011). Supporting Agricultural Innovation in Uganda to Respond to Climate Risk: Linking Climate Change and Variability with Farmer Perceptions. Experimental Agriculture, 47(2), 293-316. doi:10.1017/\$0014479710000785

43. Park, S. E., Marshall, N. A., Jakku, E., Dowd, A. M., Howden, S. M., Mendham, E., \& Fleming, A. (2012). Informing adaptation responses to climate change through theories of transformation. Global Environmental Change, 22(1), 115-126.

doi:10.1016/j.gloenvcha.2011.10.003

44. Platteau, J. P., \& Gaspart, F. (2003). The" Elite Capture" Problem in Participatory Development. Retrieved from https://crespienrico.files.wordpress.com/2008/11/elitecapture.pdf

45. Rademacher-schulz, C., Schraven, B. \& Mahama, E.S. (2014). Time matters : shifting seasonal migration in Northern Ghana in response to rainfall variability and food insecurity. Climate and Development, 6(1), 46-52. doi: 10.1080/17565529.2013.830955

46. Ray, D. (2006). Aspirations, poverty, and economic change. in Banerjee, A. V., Bénabou, R. \& Mookherjee, D. (Eds.) Understanding Poverty. New York: Oxford University Press.

47. Reser, J.P. \& Swim, J.K. (2011). Adapting to and coping with the threat and impacts of climate change. The American Psychologist, 66(4), 277-89. doi: 10.1037/a0023412

48. Rupa Kumar, K., Sahai, A. K., Patwardhan, S. K., Mishra, P. K., Revadekar, J. V, Kamala, K., \& Pant, G. B. (2006). High-resolution climate change scenarios for India for the $21^{\text {st }}$ century. Current Science, 90(3), 334.

49. Shackleton, S., Ziervogel, G., Sallu, S., Gill, T., \& Tschakert, P. (2015). Why is socially-just climate change adaptation in sub-Saharan Africa so challenging? A review of barriers identified from empirical cases. Wiley Interdisciplinary Reviews: Climate Change. doi: $10.1002 /$ wcc. 335 
50. Singh, C. (2014). Understanding water scarcity and climate variability: an exploration of farmer vulnerability and response strategies in northwest India. Doctoral Thesis. University of Reading, UK.

51. Slegers, M.F.W. (2008). "If only it would rain": Farmers' perceptions of rainfall and drought in semi-arid central Tanzania. Journal of Arid Environments, 72(11), 2106-2123. doi:10.1016/j.jaridenv.2008.06.011

52. Spence, A., Poortinga, W., Butler, C., \& Pidgeon, N. F. (2011). Perceptions of climate change and willingness to save energy related to flood experience. Nature Climate Change, 1(1), 4649. doi:10.1037/a0023253

53. Spielman, D. J., Ekboir, J., \& Davis, K. (2009). The art and science of innovation systems inquiry: Applications to Sub-Saharan African agriculture. Technology in Society, 31(4), 399405.

54. Walker, B., Holling, C. S., Carpenter, S. R., \& Kinzig, A. (2004). Resilience, adaptability and transformability in social-ecological systems. Ecology and Society, 9(2), 5.

55. Weber, E.U. (2010). What shapes perceptions of climate change? Wiley Interdisciplinary Reviews: Climate Change, 1(3), 332-342. DOI: 10.1002/wcc.41

56. Williams, L.J., Grünbühel, C.M. \& Brown, P.R. (2013). A social science framework to guide multi-scale research into climate change adaptation strategies in agricultural communities. Australia: CSIRO. Retrieved from https://publications.csiro.au/rpr/download?pid=csiro:EP12615\&dsid=DS5

57. Wolf, D. L. (1990). Daughters, Decisions and Domination: An Empirical and Conceptual Critique of Household Strategies. Development and Change, 21(1), 43-74. doi:10.1111/j.1467-7660.1990.tb00367.x 